\title{
The Lake Tahoe Collaborative Partnership: Expanding the Role of Community in Environmental Protection
}

W. Michael McDavit ${ }^{\dagger}$

W. Micloail Mil Davit is pursuing a Master of

Public Administration with a concentration in invitunmentul prolicy at The Getrige Washington University. He currently works as a Team Leidde at the U.S. Envirummental Protection Aroncy.

Mi: MeDavit recined a buibelon of scituie diarti fiom the Univinsity of Wisimsin at Grien Bay in 1079.

The opinims tapposied in this parper art those of the anthol and to mot metrongily iepresut the piems of the United Statid Enipironmental Proteitim Atruty.
A lake is the landscape's most beautiful and expressive feature. It is earth's eye, looking into which the bebolder measures the depth of bis own nature. The fluviatile trees next the shore are the slender eyelashes which fringe it, and the wooded bills and cliffs around are its overbanging brows. ${ }^{1}$

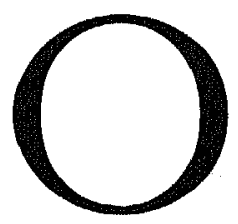

n the shores of Lake Tahoe in the summer of 1997 , a historical meeting brought together national, state, and local political figures, as well as a comprehensive array of interest groups, stakeholders, and citizens, to talk, listen, and decide the future of Lake Tahoe. Facing a steady decline in its fabled water clarity, the lake had evoked broad civic concern and received attention from nearly all political and economic quarters. Conservationists and the tourist industry alike had a great deal at stake in reversing the water quality problems of Lake Tahoe.

As important as the goal of restoring the health of Lake Tahoe was the means used to address the issue: a federal partnership joined with a community-based coalition. The federal administrative model that had been in place for years - it centralized 
Thus, the Lake

Tahoe

Partnership

represents a

dramatic

illustration of a

change in the

way the

government

addresses

problems and

relates to

people. environmental bureaucracy that establishes national standards and directs regulated parties to follow them - had been replaced with a spirit of collaboration and place-based cooperation. Thus, the Lake Tahoe Partnership represents a dramatic illustration of a change in the way the government addresses problems and relates to people.

This paper describes a situation where the president directed the federal bureaucracy to facilitate a communitybased solution to a complex environmental protection problem. Using Thoreau's prose, one could say that the participants of the Presidential Forum looked into "earth's eye," and found an explicit basis for "measuring the depth" of their own nature. By putting democratic methods to work, the federal and local actors not only pursued a cleaner and healthier lake, they discovered a near fathomless basis for cultivating civic life and reforming the administrative state.

\section{Collaborative Partnerships}

Ralph Waldo Emerson wrote that, "the wise know ... that the State must follow and not lead the character and progress of the citizen."2 Unfortunately, the federal government downplayed this maxim while implementing the current environmental regime. In the early days of the modern environmental movement, the federal government often imposed solutions without regard for the community. The establishment of acrossthe-board, national solutions was the norm.

About ten years ago, the rigid, top down, command-and-control dictates of the federal government began to be replaced by partnerships, collaborations and other less hierarchical forms of governance. These approaches had many benefits: all parties tended to share the same goals, treated each other as equals, encouraged open discussion, and sought the most effective and strategic ways to solve problems. Solutions were tailored to local conditions and needs.

In effect, these partnerships and the realignment of the federal bureaucracy appeals to the democratic spirit in citizens. Some scholars consider such trends in environmental protection as evidence of resurgence of democratic ideals and methods. Daniel Kemmis takes the view that in a republican democracy the "citizen" shapes the state and constitutes him or herself in the process. ${ }^{3}$ He believes a people and place act in a self-reflecting way - a diverse people shape themselves as a result of their common experience and common place. While inhabiting a place, a people must nurture the "civic virtues of trust, honesty, justice, tolerance, cooperation, hope and remembrance" in order to cultivate civic and democratic life. ${ }^{4}$ Applying such virtues while solving complex problems serves to restore democracy.

Partnerships and community-based solutions, for all their benefits, do not come easily. Kemmis suggests that citizens often fail to "recognize the common ground" within their communities and squander the immense potentialities contained within such commonness.5 Additionally, people have grown accustomed to disunity and adversity in public life and take for granted government intervention as a means of solving problems. 
Thus, in order for partnerships and community-based processes to be most effective, certain basic conditions must be met. Citizens must rely on mutual trust as a basis for achieving political solutions. To realize a common ground and its hidden potential, citizen disillusionment with government and apathy toward politics must be discarded in favor of a spirit of pragmatic optimism. Cynicism about the current political predicament - blaming the over-bureaucratization of public affairs and the subsequent isolation and disenfranchisement of the citizen ${ }^{6}$ - has to be replaced by a willingness to try reasonable, decentralized options to solve complex problems.

The current administration's effort to overhaul the federal government, through the work of the National Performance Review (NPR), has reached similar conclusions. In 1993, NPR concluded that the federal bureaucracy's appetite for red tape, and a centralized orientation to problem solving frustrated good government. 7 In response to those findings and others, NPR aimed to revitalize State and Local government and to promote a new emphasis on local problem solving.

\section{Decentralizing Environmental Protection}

If the bureaucracy helped to create the political crisis, it is a fair premise that the public administrator will play an integral role in developing solutions. The federal government has responded with decentralized forms and institutional experiments in recent years. Communities like Lake Tahoe which have begun building bridges and finding "common ground," appear particularly ripe for reversing the ineffectiveness of the modern administrative state.

How does a collaborative partnership or partnership differ from any other federally-based cooperative effort? While the difference may be only a matter of degree, there appear to be some distinguishing features. The terms, collaborative partnership and partnership, are often used interchangeably. The term partnership alone may confer a meaning of inter-agency and/or intergovernmental cooperation, limiting itself to governmental actors. More traditionally, partnership referred to a formal publicprivate contractual arrangement. In stark contrast, a collaborative partnership usually implies a less formal arrangement that includes a host of intergovernmental actors, as well as actors from the private and/or not-for-profit sectors. The terms, however, are neither absolute, nor mutually exclusive.

More importantly, a partnership or collaborative partnership, in the reinvention context, differs by its representation of a new type of relationship with the involved entities. In today's jargon, to collaborate or partner with the federal government is meant to convey a shared, integrative responsibility. Instead of reflecting a top down relationship, the federal government attempts to work as an equal partner with other public and private entities. In collaborative partnership, the federal government acts in a manner that minimizes governmental fragmentation (across jurisdictions), emphasizes prevention rather than compliance and enforcement, and attempts to align scarce resources (regardless of source) to some societal goal.
To realize a

common

ground and its

hidden

potential,

citizen

disillusionment

with

government and

apathy toward

politics must be

discarded in

favor of a spirit

of pragmatic

optimism. 
Instead of

reflecting a top

down

relationship,

the federal

government

attempts to

work as an

equal partner

with other

public and

private entities.
Although the Clinton Administration cannot take credit for inventing the idea of the federal-local partnership, recent NPR activities have certainly given partnerships a boost. In the NPR report, Businesslike Government: Lessons Learned from Americas Best Companies, Vice President Gore concluded that regulators are more effective in partnership with industry than as watchdogs. ${ }^{8}$ And in the Blair House Papers, the administration reminded the bureaucracy to, ". . . get out of Washington and create grassroots partnerships," rather than focus efforts on strict enforcement.?

Congress has also seen the merit of partnerships as an administrative method. For example, Congress recently passed a landmark law to authorize the collaborative partnership method for the U.S. Fish and Wildlife Service (USFW). The National Wildlife Refuge System Volunteer and Partnership Enhancement Act, signed into law on October 5, 1998, provided a much clearer authorization for the USFW to organize and collaborate directly with non-federal organizations, including community level groups. ${ }^{10}$

In the environmental protection arena, community-based approaches have also been on the rise due to encouragement from the Executive Branch ${ }^{11}$ and from endorsements by reputable non-government sources. For instance, the National Academy of Public Administration, the Keystone Center and the Center for Strategic and International Studies joined forces, convening a large stakeholder group under the name, Enterprise for the Environment (E4E). The E4E explored ways to reform the country's environmental protection programs and institutions.
As the most comprehensive evaluation of the U.S. environmental protection system undertaken to date, the $\mathrm{E} 4 \mathrm{E}$ concluded inter alia that there was a need to address newly emerging environmental problems, particularly non-point source water pollution crises. In addition, E4E sought to make the new environmental protection system as efficient and inexpensive as possible. In its recommendations, E4E suggested that the environmental policymaker should: seek equity in achieving environmental standards; use flexible means, coupled with responsibility, accountability and transparency; place decisions and programs at appropriate levels of government; promote collaborative problem-solving and integrated policy-making; promote environmental stewardship and continuous improvement; and create "decision processes" that meaningfully involve stakeholders and all citizens. ${ }^{12}$

Other non-governmental reformers share similar views. To better protect the environment, the Progressive Foundation advocates that the environmental bureaucracy use better priority setting, decentralize decision-making, exercise greater flexibility, and measure results against goals. ${ }^{13}$ Resources for the Future believes the EPA's pollution control system should act in a more results-oriented, integrated, efficient, and participatory and information-rich manner. ${ }^{14}$ The methodologies employed at Lake Tahoe provide examples of the implementation of some of these general recommendations.

Some would argue that such reform ideas and the trend towards devolution illustrate a predictable shift in the priorities of government. Herbert Kaufman observes that the history of public ad- 
ministration in this country is characterized by a cycle of emphasis on politically-neutral competence, executive leadership, and representativeness (i.e., responsiveness to the electorate or people). ${ }^{15}$ The latter is often associated with decentralization.

There is some evidence that this cycle has been at work in the environmental policy arena. The politically neutral, competent administrator has championed environmental regulation since the enactment of the present generation of environmental laws. National bureaucracies like the U.S. Environmental Protection Agency and U.S. Fish and Wildlife Service held close reigns (particularly during the1970's) on many aspects of the environmental policy and natural resource fields. During that period, an unprecedented number of national environmental laws and standards were created and implemented by the politicallyneutral and competent bureaucrat. Concentrating largely on national-scale problems, their programs included the regulation of point sources of water pollution, inclustrial and vehicular air pollution emissions, hazardous wastes and toxic chemicals, the preservation of endangered species, and the protection of critical natural habitats.

The Chief Executive has also taken a turn at leading the environmental protection effort. In spite of their differences in ideology, the Reagan, Bush and Clinton Administrations have all exerted considerable leadership in environmental protection. The Reagan Administration took an active interest, albeit adversarial one, in both the environmental programs in the U.S. EPA and the Department of Interior, and exerted considerable executive leverage. President Bush, referring to himself as the "environmental president," choreographed major revisions to the Clean Air Act and established an unprecedented interest in international environmental policy. Furthermore, important amendments to the Safe Drinking Water Act and the rigorous Food Quality Protection Act came to pass under President Clinton.

A genuine, widespread interest for a "representative," community-based approach to protecting the environment is a recent realization. Signifying a shift towards representativeness, the spreading popular appeal of devolution appears to be eclipsing the emphasis on politicallyneutral competence and executive leadership. As the environmental protection regime is decentralized, we can take heart that Herbert Kaufman in his explanation of the democratic cycle has asserted, "Wheels turning on their own axes do advance."

\section{Lake Tahoe}

. . at last the Lake ITaboel burst upon us - a noble sheet of blue water lifted six thousand three hundred feet above the level of the sea, and walled in by a rim of snow-clad mountain peaks that towered aloft a full three thousand feet bigher still. . . As it lay there with the shadous of the mountains brilliantly pbotographed upon its still surface I thought it must surely be the fairest picture the whole earth affords. ${ }^{16}$

By all accounts, Lake Tahoe is a remarkable freshwater body. It measures roughly twenty-two by twelve miles and is the third deepest lake in North America. In fact, the lake holds enough
Signifying a

shift towards

representa-

tiveness, the

spreading

popular appeal

of devolution

appears to be

eclipsing the

emphasis on

politically-

neutral

competence

and executive

leadership. 
Even today, the water of Lake Tahoe is so clear that it is still possible to see down more than 100 feet. water to cover a flat area equivalent to the size of the State of California in fourteen inches of water. ${ }^{17}$ It is also the highest lake of its size in the United States (6225 feet above sea level), and ranks among the most beautiful and clear freshwater bodies of the world. Even today, the water of Lake Tahoe is so clear that it is still possible to see down more than 100 feet.

As is the case for most lakes, Lake Tahoe is aging through the nutrient-enriching process of eutrophication. However, the process of aging in Lake Tahoe has been accelerated by the elevated introduction of nutrients and sediments through human activities. Many bodies of water typically suffer from the direct or point source introduction of nutrient-rich water pollution, such as the discharge from a sewage treatment plant. Such direct discharge points, however, no longer exist in the Tahoe basin. Instead, Lake Tahoe receives the limiting nutrients, phosphorus and nitrogen, from non-point sources of water pollution. Indirect sources include the air deposition of air pollution particles and gases, and the erosion of sediments within the drainage basin. The loss of pollution-absorbing habitat and natural ground cover exacerbates both of these non-point source processes.

In a lake, the greater availability of nutrients leads to an increase in algae growth and productivity, which in turn leads to an increase in turbidity and a decrease in water clarity. In addition, sedimentation tends to fill in a water body, contributes to the nutrient load, and leads to a decline in water clarity and quality.
Due to Lake Tahoe's incredible depth, the lake acts as a "nutrient sink not subject to [the] flushing action" that exists in shallower lakes. ${ }^{18}$ This means that everything that enters Lake Tahoe tends to stay there - nutrients, toxic materials (and maybe even tourists). To maintain water quality in such a lake, one must reduce inputs of water quality impairing pollutants, particularly the nutrients that contribute to eutrophication.

Lake Tahoe has long been recognized as one the Nation's most beautiful natural assets. It was one of the three natural wonders originally considered for the establishment of the National Park system. ${ }^{19}$ The other two, Yellowstone and Yosemite, were eventually granted National Park status.

The lake has meant many different things to different people. Many residents are connected to the lake's world class recreational and resort industry. The Lake Tahoe region offers skiing in the winter, and boating, fishing and other outdoors activities in the summer. Year round, the Nevada side of the lake also serves as a major gambling hub. Thus, tourism of all sorts is the main lifeblood of the Lake Tahoe Basin.

Other stakeholders include the local Washoe Indian Tribe, who have long revered the lake for spiritual reasons. ${ }^{20}$ However, since the Gold Rush and timber era of the last century, the tribe has not had direct access to the lakeshore. In addition, the lake has been a rallying point for local conservationists. Moreover, the farmers downstream of the lake utilize the bountiful waters of Lake Tahoe as a vital source of irrigation water. 
What these disparate, competing stakeholders share in common is the lake. Upon the physical landscape, the people's "common ground" for furthering their diverse lifestyles and values is Lake Tahoe itself. The residents, whether permanent or temporary, depend on the lake and the lake depends on them. The lake constitutes them as a people. It is the constant backdrop and stage for displaying divergent community values.

To help cope with the competing interests for the lake, California and Nevada established the first bi-state regional (environmental) planning agency in the country. ${ }^{21} \mathrm{~A}$ compact between the states created the Tahoe Regional Planning Agency (TRPA) to resolve land use planning and environmental problems in the Lake Tahoe basin. ${ }^{22}$

Despite its innovative ways, the TRPA has faced numerous obstacles since its inception. In the 1980's, funding for the regional agency almost dried up. TRPA has faced numerous civil law suits. While many legal issues were small, others were far-reaching and touched on controversial land use issues. From these experiences, TRPA and the other local stakeholders learned that consensus and cooperation are cheaper and more effective options for reaching environmental goals than litigation and community derision.

The uniquely situated TRPA continues to serve as the planning lightning rod for the basin. Most recently, TRPA developed an Environmental Improvement Program, which established environmental threshold standards. To achieve these standards, substantial support would be needed from the various stake- holders in the Lake Tahoe Basin, including the federal government.

\section{The Presidential Forum}

At the specific request of U.S. Senator Reid of Nevada, President Clinton agreed to hold a high-level forum for creating a plan to save Lake Tahoe in July, 1997.23 Senator Reid considered the situation ripe for intervention, recognizing that the solution to Lake Tahoe's water problems were, to a large degree, in the hands of the federal bureaucracy. Nearly 75 percent of the Lake Tahoe watershed is under the stewardship of the U.S. Forest Service.

While not downplaying the critical role of Senator Reid and the president, the true foundation for what would take place at Lake Tahoe was borne in the alpine air of the Sierra Nevadas. The local collaborations - the ones being built on the "common ground" of improving the lake and the area's livelihood - were presumably the real driving force behind the event. But as Kemmis suggests, the "common ground" represents only one of two ingredients needed to realize community progress. The second ingredient, the realization of the potentialities contained within the common ground, was also necessary. Recognizing that the administration was keen on partnership initiatives, Senator Reid's invitation to the White House and the president's acceptance, helped to turn a potentiality into a reality.

In preparation for the Presidential Forum, the organizers held three separate consensus building conferences around inter-related local themes: (1) water quality, (2) forest ecosystem restoration, recre-

\section{What these}

disparate, competing

stakeholders

share in

common is the

lake. 
The ability of

the federal

partners to

adapt to this

setting was

also made

possible by the

concurrent

adoption of the

partnership

method in the

federal

bureaucracy. ation, and tourism, and (3) transportation. Each of these conferences, chaired by high-level federal officials, were held about one month prior to the forum and served to focus the needs of the community. This set the stage for establishing a patchwork of federal supports and networks. Performance measures were identified, and the research needs of the collaborating scientific bodies were coordinated. Redundancies were identified across federal and state agencies, and innovative pilot projects were brought to the fore.

The local stakeholders, collaborators, and regional/local representatives from state and federal agencies worked together to develop the plan and agenda for the forum. The U.S. EPA Administrator, Carol Browner, co-chaired the Water Quality Conference. In her opening remarks, Administrator Browner set the stage for a grassroots perspective on the initiative, "I want to stress that the greatest promise come from you - the people who care about the health of this lake and are moving Heaven and Earth to ensure that this remains one of the nation's most enchanting places to live and visit." 24 While acknowledging a national stake, she also placed more emphasis on the idea of augmenting and facilitating the existing "collaborative partnership" created by the efforts of the local stakeholders, rather than dictating a federal solution. This theme, that the collaboration was already fundamentally in existence and that the federal roles were limited to endorsement, stewardship of federal lands, and fiscal support, was evident in many of the remarks, speeches and accounts of the preceding conferences, as well as the forum itself. 25
The ability of the federal partners to adapt to this setting was also made possible by the concurrent adoption of the partnership method in the federal bureaucracy. For instance, in the strategic plans of many of the nation's departments and regulatory agencies, "partnership" now serves as a fundamental tool. The U.S. Departments of the Interior and Agriculture, and the U.S. Environmental Protection Agency all cite "partnering" with public and private entities as a strategic way to meet performance goals. ${ }^{26}$

Within the framework of communitybased environmental protection, the most crucial elements of a successful program are building the program up from the grassroots, and making it inherently flexible - adaptable to the community's situation and values. ${ }^{27}$ If executive leadership acts in too prescriptive a manner within such a setting, the citizens, stakeholders and even the ground-level bureaucrats involved in the action will likely disengage without having reached tangible results. Thus, impersonal and top down administration is mutually exclusive of legitimate, community-based environmental protection programs.

The community collaborators who were moving toward "common ground" prior to the forum included the Tahoe Transportation Coalition, the Tahoe Truckee Regional Economic Coalition, the Tahoe Coalition of Recreation Providers, the Forest Health Consensus Group, the Washoe Tribe of Nevada and California, and the Tahoe Center for a Sustainable Future. In addition, the longstanding research cooperatives, including the Tahoe Research Group, the Lake 
Tahoe Area Council, and the Lake Tahoe Interagency Monitoring Program were also involved. ${ }^{28}$ As described by TRPA's Executive Director, James Baetge, the work of these organizations and crosscutting groups made the time right for collaboration with the Federal government. ${ }^{29}$

The president must be given due credit for showing restraint in not exacting the usual command-and-control response. However, his role was also not merely limited to drawing the spotlight. President Clinton issued an Executive Order (EO), implementing a new vision of how the administrative state could assist the people of Lake Tahoe. He was actually the third president to issue an EO concerning Lake Tahoe in the last twenty years. President Carter issued EO 12247 in 1980, which created a special nine-member Lake Tahoe Federal Coordinating Committee to investigate continuing water quality problems in the Lake Tahoe Basin. And President Reagan, under the rubric of "New Federalism," issued EO 12298, which gave greater deference and discretion to the States to handle the matter: But ironically, President Clinton's EO appeared to exceed the federalism or devolution standard set by the Reagan administration, and simultaneously instructed the involved federal bureaucracies to step up their actions.

The participants of the Presidential Forum included many of the same officials who attended the pre-forum conferences, spanning virtually all of the involved federal, state, and local government entities, as well as interest groups and private sector players. In addition to the president and vice president, federal actors included three cabinet members, the Administrator of the Environmental Protection Agency, and an Assistant Secretary of the Army. Elected officials included three U.S. senators, five U.S. representatives and the governor of Nevada.

The president and other executives clearly were interested in holding a meeting comparable in scale to a Heads of State Summit. Yet, from all accounts, this array of powerful people did more listening than talking. There seemed to be a genuine attempt at allowing the affected parties, who were also in attendance, to call the shots and set the agenda.

As mentioned above, to ensure the federal government's part in the arrangement, President Clinton signed Executive Order 13057, Federal Actions in the Lake Tahoe Region, at the completion of the two-day forum. ${ }^{30}$ Citing the public law that first recognized the compact between California and Nevada, EO 13057 recognized Lake Tahoe as "an area of national concern" and spelled out the initial responsibilities of the federal government. The thread throughout the EO is the necessity for full coordination across all federal activities operating in the Tahoe Basin area. To ensure intergovernmental cooperation, the EO also called for the establishment of a Memorandum of Agreement (MOA) with California, Nevada, the Washoe Tribal Government, TRPA, and local governments, which has since been executed.

The president committed the federal government to a substantially greater investment of fiscal and manpower resources towards efforts to protect the Lake Tahoe Basin, and spelled out the ar-
Thus,

impersonal

and top down

administration

is mutually

exclusive of

legitimate,

community-

based

environmental

protection

programs. 
In his original

written

commitment,

the president

focused on two

general

themes:

protecting the

lake and the

local economy,

and working as

a partner. eas of greatest importance to his Cabinet and the Congress. The other partners rightly expected substantial fiscal support from the federal government, given the vast area of the surrounding watershed under the care of the USDA Forest Service.

In his original written commitment, the president focused on two general themes: protecting the lake and the local economy, and working as a partner. 31 Under the first theme, he emphasized water clarity, preventing catastrophic fire and improving transportation services all directly or indirectly connected to water quality and the quality of life in the Lake Tahoe Basin. In total, the president specified some 28 federal actions under these various headings that the appropriate federal agencies were instructed to execute, including the reintroduction of the practice of prescribed burning. The number of actions, while important, is a little misleading because many of these were already underway. The promise of increased funding, however, certainly served to invigorate the endeavors already in progress.

More importantly, the selection of these federal actions resulted from the participation-rich consensus process of the stakeholders. Since the conclusion of the forum, the list of actions has grown to 39. Of these, four of them involved no new federal outlays in fiscal years 1997 and 1998. These four actions constituted new agreements or understandings, and laid the foundation for future cooperation and partnership with the federal government.

In summary, these commitments put the federal agencies in the position of placing greater priority on developing a unified goal, and integrated the existing fragmented programs. Coupled with the inter-governmental MOA, these actions helped to align activities and scarce resources across all public sources of financing. The TRPA Executive Director, James Baetge, believes an important result of the forum was its effect of consolidating the funding parties, including private sector players. ${ }^{32}$ The president's commitment was to double federal expenditures over the next few years, increasing the fiscal year 1997 allotment of about $\$ 8$ million to nearly $\$ 20$ million in fiscal year 1998 .

\section{Results of the Lake Tahoe Partnership}

The Lake Tahoe Partnership could serve as a prototype for similar participatory actions. The partnership appears to have reversed at least one pattern associated with many other participatory forms of program administration. Whereas Foley indicts most federal efforts for failing to involve citizens in federal programs in a timely manner, 33 this collaborative partnership developed as a result of pre-existing, grassroots collaborations that collectively appeared to set their own agenda. Their contribution was not "late" in the federal implementation process. Aside from the earlier conferences, it is almost an understatement to say that there were many pre-existing collaborations in the works, developing ideas, solutions, etc., well before the forum was ever planned.

The forum has encouraged an increased effort to coordinate within, among, and between federal and non- 
federal entities. In addition, the event served to encourage the implementation of "new" actions (originally 28), most of which fell within the themes covered by the three conferences prior to the forum. From the perspective of dedicated resources, the fecleral government has already lived up to its promise to double the federal investment. The $\mathrm{EO}$ specifically directed better interagency coordination, and established an Executive coordinating Committec, chaired by USDA Secretary Glickman in the first year. A federal advisory committee, named the Lake Tahoe Basin Advisory Committee, was also chartered as scheduled. This body continues to advise the Tahoe Federal Interagency Partnership as it moves forward.

A progress report was issued in March, 1998, giving a line-by-line accounting of each commitment made by the president. ${ }^{34}$ The status report covered the then 39 actions. The actions related to improving the overall environmental quality of the Basin, reducing the inputs of pollutants to the watershed (especially nonpoint sources of water pollution), and maintaining the region's recreational vitality. All of the actions were peppered with coordination and integration, relevant federal actions would no longer be implemented in a vacuum at Lake Tahoe.

For example, the USFS has provided funding for conducting various environmental impact assessments and has established an agreement with the Washoe Indian Tribe. The agreement provided the tribe with a special permit, allowing them to manage a 350-acre tract. This permit grants the Tribe direct access to the water's edge for the first time in over a century. At the forum, the president's "emotional promise to help restore the Washoe to Lake Tahoe got the most applause" over all other federal pledges. ${ }^{35}$

The U.S. Forest Service (USFS) of the USDA has also provided funding to close 116 miles of obsolete, abandoned logging roads, and to improve another 168 miles of logging roads in the Lake Tahoe Basin. The projected expenditure for fiscal years 1997 and 1998 totaled more than $\$ 1.6$ million. This action will reduce the runoff of sediments and restore the pollution-absorbing capacity of the forest.

In addition, the U.S. Department of Transportation's (DOT) Federal Highway Administration provided funding to the Nevada Department of Transportation (NDOT). This funding was devoted to the purpose of establishing high-tech weather stations, which provide early warnings for weather changes. NDOT has reported that the new technology has already reduced the use of sand and salt on Nevada roads in the Tahoe Basin by 75 percent. ${ }^{36}$ California is now considering the installation of similar technology. These actions serve to reduce the introduction of harmful sediments into the basin.

\section{Potential Pitfalls of Partnership}

Despite the impressiveness of the Lake Tahoe Partnership, aspects of the President's initiative are subject to question. Was the President merely grandstanding or co-opting the legitimate efforts of the Lake Tahoe stakeholders? What will sustain this assemblage of actors and fiscal commitments over time? Is the forum just another example of the
All of the

actions were

peppered with

coordination

and integration,

relevant federal

actions would

no longer be

implemented in

a vacuum at

Lake Tahoe. 
At this

juncture,

devolving

some programs

and

encouraging

greater public

participation

seem to be

worthy

experiments. government caving-in to special interests? More importantly, at a time of fiscal austerity, does a small alpine lake warrant such national attention and federal fiscal commitment?

Environmentalists ponder the merits of devolution efforts, highly suspicious of efforts to devolve national programs. Because they are wary that local parochial interests will trump environmental interests, some environmentalists are fearful of the devolution of pollution control regulation and natural resource management to lower levels of government. The League of Conservation Voters (LCV) considers such moves as commendable on some grounds, but concludes that devolution is potentially fraught with environmental risk, social and economic inequity, and enforcement malfeasance. 37

In the face of many unsolved environmental problems, using the traditional national standards approach to environmental protection may pose a greater risk than those threats considered by the LCV. Citizens have also become increasingly estranged from their government, partly as a result of the centralized, technocratic bureaucracy defining and solving their problems. At this juncture, devolving some programs and encouraging greater public participation seem to be worthy experiments. In the process, if citizenship and democratic forms were reinvigorated while citizens explore environmental solutions, the fears of LCV would prove exaggerated.

The president may have been using new democratic forms, but there was little evidence of political gamesmanship. Rather, the president was exploring new forms to solve old problems, while looking to a shared power base to derive the solution. At best, the president was using his influence to allow "leadership [to] emerge from the 'communities of interest' - communities that must discern ways of working effectively with each other," instead of imposing one-size-fitsall remedies baked in Washington, 38

The act of uniting parties, through "partnership," with the existing populistlike agenda for saving Lake Tahoe, also makes for an enigmatic combination. In its worse light, as some critics of the recent reinvention reforms might suggest, an event like the Lake Tahoe Collaborative Partnership could be reduced to mere post-modern symbolism. 39 These critics might predict that for want of a theoretical foundation, the "partnership" as another reinvention form has served only political expedience, forfeiting any lasting effects in democratic governance. Such a rebuff would be based on the premise that many of the reinvention reforms under the Clinton administration have lacked a unifying theory, instead thriving only in the fleeting moment of today's "hyperreal" expressions.

A preoccupation with the political role of the federal government in such an arrangement, and relying on the event's political packaging and use of hackneyed terms-of-the-day to communicate its value, may indeed pose a risk of trivializing any legitimate political and environmental protection gains made at Lake Tahoe,

The head of TRPA, although confident and optimistic, is careful not to reduce the collaborative partnership to mere political buzzwords; 
I think this is a new step in problem solving - I dislike giving it a name, as that tends to date such activities as new methods appear on the scene. I believe the Taboe Basin is in a certain stage of development that was ripe for a collaborative process to occur. Not all parts of the country bave gone through 25-30 years of conflict (bopefully not a prerequisite to collaboration), but perbaps we can serve as a model to be followed in other areas where there is an extremely complex mix of development and environmental protection needs. ${ }^{40}$

He makes a strong case that the partnership and CBEP efforts are not merely the "hyper-real," but have substance. This substance is the product of the trust established by a people over an extended time frame. The efforts at Lake Tahoe are neither trivial, nor mere symbols. A cynical observer might still conclude that the event was just another "sound bite" for the White House. But post-modernism symbolism appears to play a minimal role in the dynamic at work in Lake Tahoe.

Despite the enigmatic appearance of the Lake Tahoe Collaborative Partnership, place-based politics can co-exist within the tension of partnering with government bureaucracies. Enigma does not necessarily spell incongruence in this case. Perhaps the critics of NPR are partially correct, that the underlying public administrative theory for a federal partnership, furthering a place-based solution to a local problem, is not well established.

Yet, there are some legitimate sources of democratic theory present in the Lake Tahoe Partnership and the
CBEP activities. Kemmis' places-based theory, for example, is well grounded in neo-republicanism or populism. And while acknowledging that "partnership" is a metaphor, both the term and its application are legitimate, especially in regard to intergovernmental relations and the growing attention on performance goals in government circles. In addition, democracy itself may posess sufficient breadth to encompass such decentralized forms. Elton Mayo notes that the government's command or top down role is proper under emergency conditions (such as during war), but other times warrant another more potent, appropriate form of democracy. Today, Mayo might counsel that the time is right for "spontaneous and cooperative control" from the bottom up. ${ }^{41}$

The ability to sustain a collaborative effort over a long time horizon presents a more concrete problem. Fiscal resources or political priorities could shift and, like Cinderella, Lake Tahoe may find that her royal coach (the federally-backed partnership) has turned into a pumpkin and the footmen (the feds) have scattered away like tiny mice. This vulnerability reveals one of the weaknesses of such ad hoc approaches to problem solving and program administration, particularly when juxtaposed against more common bureaucratic norms. Lacking the staying power of normal regulatory structures, such community-based collaborative programs may dwindle with the changing of the guard. That is, as new political players are elected, old promises may fade in the din of new problems and crises.
In its worse

light, as some

critics of the

recent

reinvention

reforms might

suggest, an

event like the

Lake Tahoe

Collaborative

Partnership

could be

reduced to

mere post-

modern

symbolism. 


\section{Lacking the} staying power of normal regulatory

structures, such community-

based collaborative

programs may dwindle with the changing of the guard.
Critics like Theodore Lowi, who are suspicious of the government catering to special interests, might also charge that the Lake Tahoe Partnership is just another informal arrangement, depriving the country of better representative governance and decision-making. ${ }^{42}$ These concerns, however, will be best decided not on the program's merits and its ability to improve water quality, but rather on its legitimacy as a democratic form. This is where such criticisms miss the mark. The event is fundamentally an example of grass roots democracy at work, and while special interests participated, the "common ground" reached appeared to transcend special interest politics.

A more compelling argument regarding the legitimacy of the collaborative partnership would focus on the magnitude of resources dedicated to the effort, rather than on its appearance as special interests run amuck. Viewing this effort at a time of scarce federal resources may raise the question of whether the outcome is worth the costs, particularly when considering areas of the country with far more serious community development and water quality problems. The president may have overstepped his authority in earmarking so much federal money for such a relatively small environmental problem. This, indeed, is one of the political dilemmas of CBEP and the federal facilitation of such programs. There are, after all, limited resources and many polluted watersheds.

Recalling the comment of the Executive Director of TRPA, however, the partnership and the president's fiscal commitment may have actually helped to better manage the available fiscal re- sources. Instead of wasting precious resources, the partnership may have had the opposite effect by reducing duplication and minimizing fragmentation among and between federal, state, and local actors.

\section{Conclusion}

At the end of the forum, President Clinton not only lauded the framers of the collaborative partnership, he surrendered a portion of his "own turf" when he said during his closing remarks,

...you bave proved that you can bring all these people together and demolish the false choice between the environment and the economy. . - Community-based solutions only work when people come together, agree on a common goal, share values, and are willing to give up a little of their own turf in order to work together to a common goal. 43

Alternative place-based approaches and collaborative partnerships show promise and may represent an important trend in public administration. More importantly, these partnerships may contribute to a renewal of civic society. Although there are a few potential pitfalls, these methods may signify greater good on the democratic governance continuum. Replacing the more familiar command-and-control or one-size-fits-all approaches will take time and adjustment. The growing, more holistic forms of environmental protection - particularly when applied to place-based issues have shown promise at Lake Tahoe. Participation of stakeholders and the citizenry at large in these newer decision processes are inextricably critical to success. 
The environmental administrator, however, need not entirely abandon the command-and-control role still prevalent. But President Bush's "gentler and kinder" ideal for government is indeed translating into new roles for the bureaucrat. The activities at Lake Tahoe support the idea that bottom up roles, such as mediator, facilitator, and integrator, are on the rise in the federal government. These roles will continue to increase in importance and relevance, as administrators and citizens experiment with democratic forms to solve complex problems like those found at Lake Tahoe. In these settings, the federal environmental administrator facilitates more than controls, mediates more than adjudicates, and integrates more than defends. Participation of stakeholders and citizens in these newer decision processes are redefined under a more decentralized environmental protection system. Lake Tahoe may provide new foundations for the legitimacy of administration and its exercise of power and authority, one "founded on more direct linkages with the people." 44

Extrapolating from this partnership comes with risk, however, for other reasons. The nature of the problem - to retain Lake Tahoe's clarity and beauty was sufficiently narrow and clear to allow many diverse players to reach common ground. It may be foolhardy to project such success onto other areas of the country without considering whether or not the cause itself posesses sufficient meaning to carry it. Comparable worth and valuation could be expected at nationally renowned places like the Grand Canyon or Yosemite. However, it is not clear whether this scenario would play out in the same manner for a watershed, or other natural site more modest in scale. Kemmis, however, might suggest that the only critical factors are "common ground" and a citizenry prepared to cooperate.

The support of key political figures, especially congressional players, is also necessary for sustaining such innovative forms. Without such political support, any gains made at Lake Tahoe could diminish with time. Interestingly, some scholars have indicated that the near absence of congressional involvement was one of the biggest mistakes made by the Clinton administration during the early phases of the National Performance Review. Reinvention activities early in the Clinton administration failed to adequately involve - to partner - with members of Congress. ${ }^{45}$ It would be tempting to conclude that the administration had learned a lesson and applied it to the forum.

Lake Tahoe serves to illustrate that a transition from the "emergency" form of democracy is possible, and is brought to bear by the people and their elected leaders. People with "common ground" can govern themselves. In this case, the transition to a bottom up form of democracy came with a helping hand from the president and the federal bureaucracy. Interestingly, America's treasured natural places, like Lake Tahoe, often serve as rallying points for democracy in action. Walt Whitman contends that such responsiveness to nature is uniquely American and vital to our make-up as a democratic people:

American Democracy, in its myriad personalities, in factories, work-shops, stores, offices - through

\section{Although there}

are a few

potential

pitfalls, these

methods may

signify greater

good on the

democratic

governance

continuum. 
the dense streets and bouses of the cities, and all their manifold sophisticated life - must either be fibered, vitalized, by regular contact with out-door light and air and growtbs, farm-scenes, animals, fields, trees, birds, sun-warmth and free skies, or it will certainly dwindle and pale. We cannot bave grand races of mechanics, work people, and commonality, (the only specific purpose of America,) on any less terms. I conceive of no flourishing and beroic elements of Democracy in the United States, or of Democracy maintaining itself at all, without the Nature-element forming a main part - to be its bealtbelement and beauty-element - to really underlie the whole politics, sanity, religion and art of the New World. 46

The collaborative partnership that Forum of 1997 facilitated the democratic progress made by the area's stakeholders and citizens. making and participatory forms of policy implementation can work. Whether or not this particular political experiment produces a clearer Lake Tahoe is less important then. More importantly, the community of Lake Tahoe has renewed its confidence in the body politic, a gain that is incrementally transforming the modern administrative state.

\section{Notes}

II would like to give a heartfelt thanks to my article editor, Ilan Haber, and associate editor, Krishnan Sudharsan, for their near-perfect advice and untiring encouragement. I would also like to thank Meredith McWade and Jill Kasle for pushing me beyond my usual limits. And lastly, I would like to thank Cynthia McSwain who proved once again that you can still terch an old dog new tricks.

1 Henry David Thoreau, Walden or Life in the Woods. (Norwalk, CT.: Easton Press, 1981), 193.

2 Ralph Waldo Emerson, The Essays of Ralph Waldo Emerson. (Norwalk, CT.: Easton Press, 1979), 227.

3 Daniel Kemmis, Community and the Politics of Place (Norman, OK.: University of Oklahoma Press, 1990).

4 Ibid., 119.

5 Ibid., 64.

6 See Harry Boyte, Commonwealth: A Retum to Citizen Politics (New York: Free Press, 1989) 1-15; Kemmis, 40-64; Cheryl $S$. King and Camilla Stivers, "Introduction: The Anti-Government Era" in Government is Us: Public Administration in an Anti-Government Era (Thousand Oaks, CA: Sage Publications, 1998), 3-12.

7 Albert Gore, Red Tape to Results: Creating a Government that Works Better and Costs Less (Washington, D.C.: National Performance Review, 1993).

8 Albert Gore, Businesslike Government: Lessons Learned from Americas Best Companies (Washington, D.C.: National Performance Review, 1997), 79-81. 
9 William J. Clinton and Albert Gore, "The Blair House Papers" (January 1997); available from http://www.npr.gov/library/papers/bkgrd/blair. html; INTERNET.

10 See U.S. Department of the Interior, "News Release: Fish and Wildlife Service Hails Volunteer-Partnership Enhancement Act," (7 October 1998); available from http://www.fws.gov/r9extaff/pr9858.html; INTERNET.

11 See U.S. Environmental Protection Agency, EPA Strategic Plan, (Washington, D.C.: USEPA), 83-85.

12 See National Academy of Public Administration and Keystone Center. The Environmental Protections System in Transition: Toward a More Desirable Future (Final Report of the Enterprise for the Environment).

(Washington, D.C.: Center for Strategic and International Studies Press, 1997), 2-14.

13 Debra S. Knopman, Second Generation: A New Strategy for Environmental Protection (Washington, D.C.: Progressive Foundation, April 1996), 5-8.

$14 \mathrm{~J}$. Clarence Davies and Jan Mazurek, Regulating Pollution: Does the U.S. system Work? (Washington, DC: Resources for the Future, 1997), 48-50.

15 Herbert Kaufman, "Administrative Decentralization and Political Power," in Classics of Public Administration, edited by Jay $M$. Shafritz and Albert C. Hyde (Fort Worth, TX: Harcourt Brace College Publishers, 1997), 289298.

${ }^{16}$ Mark Twain, Rougbing it (Avon, Connecticut: Heritage Press, 1972), 115.

17 See U.S. Department of Agriculture, "Lake Tahoe Facts,"(September 1998); available from http://www.fs.fed.us/outernet/htnf/ laketaho,htm; INTERNET.

18 Deborah L. Elliott-Fisk, et al, Lake Tahoe Case Study, Addendum to the Final Report to Congress on Status of the Sierra Nevada, (Davis, CA: University of California, Davis, 1996), 227228.

19 Ibid, 218.

20 Ibid., 233.
21 See Tahoe Regional Planning Agency, TRPA Background (September 1998); available from http://www.ceres.ca.gov/trpa; INTERNET,

22 See Gary A. Horton, Truckee River Cbronology: A Cbronological History of Lake Tahoe and the Truckee River and Related Water Issues, (Carson City, NV: Nevada Division of Water Planning, April 1997), III-28; Douglas H. Strong, Taboe: An Environmental History (Lincoln, NE: University of Nebraska Press, 1984), 149-193.

23 See Harry Reid, "Harry Reid and the Presidential Forum at Lake Tahoe." ( 8 September 1998); available from http://www,senate.gov/ $\sim \mathrm{reid} /$ issu_tahoe.htm; INTERNET.

24 Carol Browner, Remarks Prepared for Deliwery Water Quality Conference, Tallac Historic Site, California, June 18, 1997 (Washington, D.C.: U.S. Environmental Protection Agency, 1997), 2.

25 Pamela B.Wilcox, electronic mail to author, 18 October 1998.

26 See U.S. Department of the Interior, "Strategic Plan Overview," 30 September 1997; available from http://www.doi.gov/plan $9 x . h t m l ;$ INTERNET; U.S. Department of Agriculture, "Overview" in Strategic Plan 1997-2002: A Healtby and Productive Nation in Harmony With the Land (Washington, D.C.: USDA, September 1997) 19; U.S. Environmental Protection Agency, EPA Strategic Plan.

27 Most bottom up approaches to managing the erivironment, such as community-based or placebased environmental protection, ecosystem management or watershed management derive their validity from grassroots and are tailored to the values of the community implementing the program. For a full treatment of these approaches see Robert W. Adler, "Addressing Barriers to Watershed Protection,"

Environmental Law, Vol. 25, no. 4 (1995): 9731106; National Academy of Public Administration, Principles for Federal Managers of Community-Based Programs (Washington, DC: National Academy of Public Administration, August 1997); and U.S. Environmental Protection Agency, Community-Based Environmental Protection: A Resource Book for Protecting Ecosystems and Communities (Washington, D.C., September, 1997). 
28 Elliott-Fisk, et al, 233, 241 243.

29 James W. Baetge, letter to author, 10 November 1998.

${ }^{30}$ See President, "Executive Order 13057 : Federal Actions in the Lake Tahoe Region." (26 July 1997); available from 1.text.2 at http://www.pub.whitehouse.gov; INTERNET,

31 See a listing of the President's original commitments included in the forward to Tahoe Federal Interagency Partnership, Lake Taboe Presidential Forum: Actions to Protect Lake Taboe, Status Report, Marcb 1998 (Washington, DC: United States Geological Survey, 1998), ivvii.

32 Baetge, letter to author.

33 Dolores Foley, "We Want Your Input: Dilemmas of Citizen Participation," in Government is Us: Public Administration in an Anti-Government Era (Thousand Oaks, CA: Sage Publications, 1998), 157.

34 Tahoe Federal Interagency Partnership, Lake Taboe Presidential Forum, 1-39.

35 Jon Christensen, "At Tahoe Forum, a Tribe Wins a Deal," High Country News (Paonia, CO: 18 August 1997), 1.

36 Nevada Division of State Lands, State of Nevada, Lake Taboe, July 1998 (Carson City, NV: 1998), 1

37 See Deb Callahan, "Local Control: The Pitfalls and Promises for Environmental Protection," Speech delivered at the League of Conservation Voters Green Vote Forum, Washington, D.C., 24 April 1997; available from http://www.lcv.org/news/GVFspeech.htm; INTERNET.

38 Joyce K. Berry and John C. Gordon, editors, Environmental Leadersbip: Developing Effective Skills and Styles (Washington, D.C.: Island Press, 1993), 178.

39 Charles J. Fox, "Reinventing Government as Postmodern Symbolic Politics," Public Administration Review, Vol. 56, No. 3 (1996), 257-258.

40 Baetge, letter to author.
41 See Brian R. Fry, Mastering Public Administration: From Max Weber to Dwight Waldo, (Chatham, NJ: Chatham House Publishers, 1989), 132.

42 Theodore J. Lowi, "The End of Liberalism: The Indictment," in Classics of Public Administration, edited by Jay M. Shafritz and Albert C. Hyde (Fort Worth, TX: Harcourt Brace College Publishers, 1997), 303.

43 See President, "Closing Remarks by the President and the Vice President at Lake Tahoe Forum," (26 July 1997); available from 11.text.1 at http://www.pub.whitehouse.gov; INTERNET.

44 Gary L. Wamsley, et al. "Public Administration and the Governance Process: Shifting the Political Dialogue," in Refounding Public Administration (Newbury Park, CA: Sage Publications, 1990), 43.

45 Donald F. Kettl, "Reinventing Government? Appraising the National Performance Review," in Classics of Public Administration, edited by Jay M. Shafritz and Albert C. Hyde (Fort Worth, TX: Harcourt Brace College Publishers, 1997), 546, 554.

46 Walt Whitman, Specimen, Days in The Portable Walt Whitman (New York: Viking Press, 1976), 639-640

\section{Bibliography}

Adler, Robert W. "Addressing Barriers to Watershed Protection." Environmental Law, 25, no. 4 (1995): 973-1106.

Baetge, James W. Letter to author, 10 November 1998.

Berry, Joyce K. and John C. Gordon., editors. Environmental Leadersbip; Developing Effective Skills and Styles. Washington, D.C.: Island Press, 1993.

Boyte, Harry C. CommonWealtb: A Return to Citizen Politics. New York: The Free Press, 1989.

Browner, Carol. Remarks Prepared for Delivery Water Quality Conference, Tallac Historic Site, California, June 18, 1997. Washington, D.C.: U.S. Environmental Protection Agency, 1997. 
Callahan, Deb. "Local Control; The Pitfalls and Promises for Environmental Protection." (Paper presented at the League of Conservation Voters Green Vote Forum, Washington, D.C., 24 April 1997); Available from http://www.lcv.org/news/ GVFspeech.htm; INTERNET.

Christensen, Jon. "At Tahoe Forum, a Tribe Wins a Deal." High Country Neus (Paonia, Colo.), 18 August 1997.

Clinton, William J. and Albert Gore. "The Blair House Papers." (January 1997). Available from http://www.npr.gov/library/papers/ bkgrd/blair.html; INTERNET.

Davies, J. Clarence and Jan Mazurek. Regulating Pollution: Does the U.S, System Work? Washington, DC: Resources for the Future, 1997.

Elliott-Fisk, Deborah I. et al. Lake Taboe Case Study, Addendum to the Final Report to Congress on Status of the Sierra Nevada. Davis, CA: University of California, Davis, 1996.

Emerson, Ralph Waldo. The Essays of Ralph Waldo Emerson. Norwalk, CT: The Easton Press, 1979.

Foley, Dolores. "We Want Your Input: Dilemmas of Citizen Participation," In Government is Us: Public Administration in an AntiGovernment Era. Thousand Oaks, California: Sage Publications, 1998.

Fox, Charles J. "Reinventing Government as Postmodern Symbolic Politics." Public Administration Review Vol. 56, No. 3 (1996): 256-262.

Fry, Brian R. Mastering Public Administration: From Max Weber to Dwight Waldo. Chatham, NJ: Chatham House Publishers, 1989.

Gore, Albert, Businesslike Government: Lessons Learned from Americas Best Companies. Washington, D.C.: National Performance Review, October 1997.

Gore, Albert. Red Tape to Results: Creating a Government that Works Better and Costs Less, Washington, D.C.: National Performance Review, 1993.
Horton, Gary A. Truckee River Chronology: A Chronological History of Lake Taboe and. the Truckee River and Related Water Issues. [7th update]. Carson City, NV: Nevada Division of Water Planning, April 1997.

Kaufman, Herbert. "Administrative Decentralization and Political Power." In Classics of Public Administration, edited by Jay M. Shafritz and Albert $C$. Hyde. Fort Worth, TX: Harcourt Brace College Publishers, 1997. First published in Public Administration Review Vol. 29, No. 1 (1969): 3-14.

Kemmis, Daniel. Community and the Poltics of Place. Norman, OK: University of Oklahoma Press, 1990.

Kettl, Donald F. (1994). "Reinventing Government? Appraising the National Performance Review." In Classics of Publtc Administration, edited by Jay $M$. Shafritz and Albert C. Hycle, Fort Worth, TX; Harcourt Brace College Publishers, 1997. First published in Kettl, Donald, Reinventing Government? Appraising the National Performance Review. Washington, D.C.: The Brookings Institute, 1994.

King, Cheryl S., Camilla Stivers and Collaborators. Government is Us; Public Administration in an Anti-Government Era. Thousand Oaks, CA: Sage Publications, 1998.

Knopman, Debra S. Second Generation: A New Strategy for Environmental Protection. Washington, D.C.: Progressive Foundation, April 1996.

Lowi, Theodore J. "The End of Liberalism: The Indictment." In Classics of Public Administration, edited by Jay M. Shafritz and Albert C. Hycle. Fort Worth, Texas: Harcourt Brace College Publishers, 1997. First published in The End of Liberalism, 1st ed., New York: W. W. Norton and Company, 1969.

National Academy of Public Administration. Principles for Federal Managers of Community-Based Programs. Washington, DC: National Acadeny of Public Administration, August 1997. 
National' Academy of Public Administration and Keystone Center. The Environmental Protections System in Transition: Toward a More Desirable Future (Final Report of the Enterprise for the Environment).

Washington, D.C.: Center for Strategic and International Studies Press, 1997.

Nevada Division of State Lands. State of Nevada, Lake Taboe, July 1998. Carson City, Nevada, 1998.

President William Jefferson Clinton. "Closing Remarks by the President and the Vice President at Lake Tahoe Forum." (26 July 1997). Available from 11.text. 1 at http://www.pub.whitehouse.gov; INTERNET.

Presiclent William Jefferson Clinton. Executive Order. "Executive Order 13057: Federal Actions in the Lake Tahoe Region." (26 July 1997). Available from 1.text.2 at http://www.pub.whitehouse.gov; INTERNET.

Reid, Harry. "Harry Reid and the Presidential Forum at Lake Tahoe." (8 September 1998). Available from http://www.senate.gov/ $\mathrm{reid} /$ issu_Tahoe.htm: INTERNET.

Strong, Douglas H. Tahoe: An Environmental Hislory, Lincoln, Nebraska: University of Nebraska Press, 1984.

Tahoe Federal Interagency Partnership, Lake Taboe Presidential Forum: Actions to Protect Lake Taboe, Status Report, March 1998. Washington, DC: United States Geological Survey, 1998.

Tahoe Regional Planning Agency. TRPA Background (September 1998). Available from http://www.ceres.ca.gov/trpa; INTERNET,

Thoreau, Henry David. Walden or Life in the Woods. Norwalk, CT: Easton Press, 1981.

Twain, Mark. Roughing it. Avon, CT: Heritage Press, 1972.

U.S. Department of Agriculture. Forest Service. "Lake Tahoe Facts." (September 1998). Available from http://www.fs.fed.us/ outernet/htnf/laketaho.htm; INTERNET.

U.S. Department of Agriculture. Strategic Plan 1997-2002: A Healthy and Productive Nation in Harmony Witb the Land. Washington, D.C., September 1997.
U.S. Department of the Interior. Fish and Wildife Service. "News Release: Fish and Wildlife Service Hails Volunteer-Partnership Enhancement Act." (7 October 1998); Available from http://www.fws.gov/roextaff/ pr9858.html; INTERNET.

U.S. Department of the Interior. "Strategic Plan Overview." (30 September 1997). Avallable from http://www.doi.gov/plan9x.html; INTERNET.

U.S. Environmental Protection Agency. Community-Based Environmental Protection: A Resource Book, for Protecting Ecosystems and Communities. Washington, D.C., September, 1997.

U.S. Environmental Protection Agency, EPA Strategic Plan. Washington, D.C., 1997.

Wamsley, Gary L. et al. "Public Administration and the Governance Process: Shifting the Political Dialogue." In Refounding Public Administration. Wamsley, Gary L. et al. Newbury Park, California: Sage Publications, 1990.

Whitman, Walt. Specimen Days. In The Portable Walt Whitman. New York: Viking Press, 1976.

Wilcox, Pamela B. Electronic mail to author, 18 October 1998. 